\title{
PRACTICE GUIDELINES
}

\section{Multidisciplinary guidelines for the care of late preterm infants}

RM Phillips, M Goldstein, K Hougland, R Nandyal, A Pizzica, A Santa-Donato, S Staebler, AR Stark, TM Treiger and E Yost, on behalf of The National Perinatal Association

Journal of Perinatology (2013) 33, S5-S22; doi:10.1038/jp.2013.53

\section{IN-HOSPITAL ASSESSMENT AND CARE}

Late preterm infants (LPIs), like all other newborns, should have a qualified healthcare provider assigned to their care during the immediate postpartum recovery period following birth. ${ }^{7}$ Late preterm infants may experience delayed or inadequate transition to the extra-uterine environment, so careful consideration of staffing ratios during transition (1-12 h after birth) for this population of infants is necessary. ${ }^{8}$ Because of their increased vulnerabilities, LPIs require continued close monitoring throughout the first $24 \mathrm{~h}$ after birth. Whenever possible, mother and infant should remain together, rooming in 24- $h$ a day. Frequent, prolonged, skin-to-skin contact should be encouraged to promote optimal physiological stability. All LPIs are at risk for morbidities severe enough to require transition to a higher level of care. If an LPI is transitioned to a higher level of care, special attention should be paid to preparing the mother for going home without her newborn, and she should be monitored closely for signs of postpartum depression and posttraumatic stress disorder in the postpartum period.

\begin{tabular}{|c|c|c|}
\hline \multicolumn{3}{|l|}{ STABILITY } \\
\hline $\begin{array}{l}\text { Reducing Risks of } \\
\text { Respiratory } \\
\text { Distress } \\
\text { References: } 2,7 \\
13,14\end{array}$ & $\begin{array}{l}\text { - Monitor infant's RR and work of breathing closely by } \\
\text { visual inspection during first hour after birth. } \\
\text { - Maintain skin-to-skin contact if stable to decrease } \\
\text { infant stress, optimize respiration and oxygen saturations, } \\
\text { and protect from hypothermia-induced apnea. }\end{array}$ & $\begin{array}{l}\text { - Explain LPI's increased risk for respiratory distress and apnea, } \\
\text { including: » Immature lung development. » Decreased } \\
\text { surfactant level. » Immature control of breathing. } \\
\text { » Decreased airway muscle tone leading to decreased } \\
\text { ability to protect airway. }\end{array}$ \\
\hline
\end{tabular}

This supplement is modified and republished on behalf of the Late Preterm Infant Guidelines Steering Committee with permission from The National Perinatal Association. Correspondence: Raylene M Phillips, MD, IBCLC, FAAP, Division of Neonatology, Loma Linda University Children's Hospital, 11175 Campus Street, Suite 11121, Loma Linda, CA 92354, USA.

E-mail: RPhillips@llu.edu 


\section{HEALTHCARE TEAM}

- If signs of respiratory distress are present and persist, evaluate with pulse oximeter, stabilize infant, and consult with next-level perinatal care provider about transferring infant to higher level of care.

Reducing Risks of Hypothermia

References: 2, 7, 9, 14,16
- Maintain neutral thermal environment. » Dry infant gently after birth. » Continue skin-to-skin care with parent whenever possible. » Cover infant's back with warmed blanket. » Keep hat on infant when not in skin-to-skin contact. » Use a pre-warmed blanket during weighing. " Keep infant's bed away from air vents and drafts.

- Prevent heat loss when skin-to-skin care is not an option or is ineffective in maintaining infant's temperature. " Swaddle with double wrap. » Increase ambient temperature. » Use radiant warmer or incubator. » Assess axillary temperature to ensure $97.7-99.5^{\circ} \mathrm{F}\left(36.5-37.5^{\circ} \mathrm{C}\right)$ q $30 \mathrm{~min} \times 1 \mathrm{~h}$, then q $4 \mathrm{~h}$ for first $24 \mathrm{~h}$, then q shift until transition/discharge.

- Postpone bath until thermal, respiratory, and cardiovascular stability is well established (typically 2-12 h after birth). " Consider partial rather than whole-body bathing. " Dry infant immediately after bath and cover infant's head with dry hat. » Place infant in skin-to-skin contact with mother, if possible, for optimal warming.

- If temperature instability occurs, take actions to stabilize. If instability persists, consult with next-level perinatal care provider about transferring infant to higher level of care.

Reducing Risks of Sepsis

References: 17, 18, 19
- Identify maternal and neonatal risk factors: » Maternal Group B Strep (GBS)-positive or unknown status with inadequate antenatal antibiotic prophylaxis.

" Chorioamnionitis/maternal fever $>100.4^{\circ} \mathrm{F}\left(38.0^{\circ} \mathrm{C}\right)$ " Maternal cold or flu-like symptoms. » Prolonged $(\geqslant 18 \mathrm{~h})$ rupture of membranes. " Fetal instability during labor or delivery.

- Assess and monitor for signs of infection: " Respiratory distress, apnea. » Temperature instability. " Glucose instability, jitteriness. " Pale, mottled, or cyanotic color. » Lethargy. » Feeding problems. " Abdominal distension, vomiting.

- If signs of sepsis occur, stabilize infant, initiate septic workup (CBC, blood culture), and start antibiotics. Consult with next-level perinatal care provider about transferring infant to higher level of care.
FAMILY EDUCATION*

- Teach how to recognize signs of respiratory distress and apnea and when to alert healthcare provider for immediate evaluation of infant.

- Explain LPI's increased risk for hypothermia: » Decreased brown fat (thermogenesis) and white fat (insulation). " Increased heat loss due to higher surface-area-to-mass ratio.

- Teach importance of skin-to-skin contact in keeping infant warm.

- Stress importance of adequate clothing when not in skinto-skin contact.

- Teach how to take infant's temperature accurately.

- Explain LPI's increased risk for sepsis: » Immature immune system. " Additional risk factors, if present.

- Teach ways to reduce illness. » Wash hands, limit visitors, avoid crowds, protect against contact with sick people. " Breastfeed for as long as possible during the first year after birth or longer.

- Teach how to recognize early signs of infection.

- Inform when to alert healthcare provider for immediate evaluation of infant.
Reducing Risks of Hypoglycemia References: 7, 12, 20, 21
- Review the antepartum/intrapartum history (as described by the Association of Women's Health, Obstetric, and Neonatal Nurses [AWHONN] Assessment and Care of the Late Preterm Infant Evidence-Based Clinical Practice Guidelines) for conditions that increase the risk of hypoglycemia. » Maternal conditions: Gestational or pre-existing diabetes mellitus, Pregnancyinduced hypertension, Maternal obesity, Tocolytic use for preterm labor, Late antepartum/intrapartum administration of IV glucose, Difficult/prolonged delivery, Nonreassuring fetal heart rate pattern. " Neonatal conditions: Prematurity, Intrauterine growth restriction, Twin gestation, 5-minute Apgar score $<7$, Hypothermia/temperature instability, Sepsis, Respiratory distress, Polycythemia-hyperviscosity.

- Follow American Academy of Pediatrics (AAP) 2011 guidelines for postnatal glucose homeostasis or established hospital protocol for glucose monitoring of at-risk infants (all LPIs); serum glucose nadir occurs $1-2 \mathrm{~h}$ after birth.

- Monitor infant for symptoms of hypoglycemia.

- Facilitate feeding at breast during first hour after birth if mother and infant are stable.

- Monitor to ensure frequent ongoing feedings on demand, at least 10-12 breastfeedings or 8-10 formula feedings per day.

- Provide intervention if required: » Offer feeding (at breast if breastfeeding). » Recheck glucose $1 \mathrm{~h}$ after feeding. » If
- Explain LPI's increased risk for hypoglycemia: » Low glycogen stores. » Immature metabolic pathways to make glucose.

- Explain any additional risk factors for hypoglycemia that may be present.

- Stress importance of feeding infant frequently, at least 10-12 breastfeedings or 8-10 formula feedings per day.

- Teach how to recognize symptoms of hypoglycemia and when to alert healthcare provider for immediate evaluation of infant. 
glucose is still low or infant is unable to adequately feed, provide IV glucose and consult with next-level perinatal care provider about transferring infant to higher level of care.

Reducing Risks of - Identify maternal risk factors that may affect successfu Feeding Difficulties References: 7, 12, 22,23 breastfeeding: » Multiple gestation. » Diabetes. " Pregnancy-induced hypertension. " Chorioamnionitis. " Cesarean delivery.

- Provide assistance as needed to ensure adequate feeding frequency, at least 10-12 breastfeedings or 8-10 formula feedings per day.

- Maintain nursing staff lactation competencies consistent with scope of practice and responsibilities.

- Provide a dedicated lactation consultant, ideally an International Board Certified Lactation Consultant (IBCLC), whenever possible.

- Provide (or refer to) a feeding specialist (occupational or physical therapist or speech/language pathologist) to evaluate infants with persistent feeding difficulties.

- Adopt the Baby Friendly Hospital Initiative's Ten Steps to Successful Breastfeeding whenever possible (www.babyfriendlyusa.org/eng/10steps.html).

- Explain LPI's increased risk for inadequate feeding: » Immature suck/swallow/breathe coordination. " Inadequate breastmilk transfer due to low muscle tone, ineffective latch, and decreased stamina. " Low milk supply due to inadequate breast emptying.

- Stress the value to mother and baby of exclusive breastmilk feeding. " Explain the value of colostrum in providing immune protection and nutrition. " Reassure mothers that small amounts of colostrum are usually adequate in the first few days if baby is feeding frequently enough.

- Teach how to recognize early feeding cues: » Opening eyes. " Moving head back and forth. » Opening mouth, tongue thrusting, rooting, or sucking on hands/fingers. » Crying (a late hunger cue often leading to difficulty with latch due to infant frustration).

- Explain the probable need to awaken infant for feeds due to LPI's immature brain and increased sleepiness. " Infant will transition to full cue-based feeds when closer to term gestational age.

- Encourage mothers to ask for assistance as needed with breastfeeding or formula feeding.

- Remind mother that babies are born to breastfeed. » Review benefits of breastfeeding for baby: decreased risk of infection, diarrheal illness, Sudden Infant Death Syndrome (SIDS), and obesity. » Review benefits for mother: decreased risk of breast cancer, ovarian cancer, and osteoporosis. " Review risks of formula feeding, e.g., increased risk of infection due to increased gastric $\mathrm{pH}$ and change in gut flora, risk of cow protein allergy, increased risk of SIDS (www.health-elearning.com/articles/JustOneBottle.pdf).

- Explain reasons for formula use if formula is medically indicated.

- Explain the importance of early and prolonged skin-to-skin contact: » Promote optimal physiological stability. » Facilitate the first breastfeeding.

\section{Continued \\ Breastfeeding \\ References: 25,26 \\ - Monitor and document breastfeeding frequency. \\ - A healthcare professional with appropriate education and experience in lactation support, such as a RN, midwife and/ or certified lactation consultant, should assess breastfeeding at least twice per day by evaluating: " Coordination of suck, swallow, and breathing. " Mother's breastfeeding position and comfort. » Baby's latch and milk transfer. » Mother's questions regarding breastfeeding. \\ - Consider use of ultrathin silicone nipple shield if infant has ineffective latch or milk transfer. » Use of shield requires close follow-up by knowledgeable healthcare professional. \\ - Assess mother's level of fatigue and coping. \\ - Refer mother to a qualified lactation specialist if feeding difficulties persist.}

- Provide written and verbal information about breastfeeding and ensure mother's understanding.

- Stress the importance of frequent breastfeedings, at least 10-12 times every $24 \mathrm{~h}$, waking baby if necessary, and encourage recognition of and response to early feeding cues.

- Educate about the size of a newborn's stomach and the adequacy of frequent, small-volume feedings of colostrum. " Use the phrase "when your milk supply increases" rather than "when your milk comes in" to avoid implying that no milk is present during the colostrum phase.

- Stress the value of exclusive breastfeeding.

- Encourage mother to ask for assistance if needed.

- Explain importance of tracking voids and stools to determine adequate feeding intake: $" 3$ voids and 3 stools by day 3. " 4 voids and 4 stools by day 4 . " 6 voids and 4 stools by day 6 and thereafter. (taking care to maintain a neutral thermal environment). " Weight loss of more than 3\% per day or $7 \%$ by day 3 merits further evaluation and close monitoring.

- Document voiding and stool patterns.

Success

References: 25

Supplementation

References: 12,25
- Supplement feeds only if medically indicated. Maternal antenatal IV fluids may lead to infant diuresis in the first $24 \mathrm{~h}$, increasing infant's urine output and apparent weight loss and should be taken into consideration when evaluating the need for supplementation.

- If indicated, supplement with (in order of preference) expressed breastmilk, donor human milk, hydrolyzed formula, or formula.

- Supplement using one of the following: » Feeding tube at breast. » Cup feeding. » Finger feeding. » Bottle feeding.
- Explain reasons for supplementing breastfeeding if indicated.

- Explain options for providing supplementation, methods of delivery, and volumes to be given.

- Stress value of exclusive breastmilk feeding if possible and risks of introducing formula.

- Explain feeding plan. » Explain that supplementation may be needed until the baby appears to be growing adequately but will likely be discontinued when baby matures and adequate growth is ensured. 
- Supplement no more than recommended volumes (if breastfeeding is inadequate): » $2-10 \mathrm{~mL}$ per feed (first $24 \mathrm{~h}$ ). » 5-15 mL per feed (24-48 h). » 15-30 mL per feed (48-72 h). » 30-60 mL per feed (72-96 h).

- Evaluate continued need for supplementation with daily feeding plan.

- Evaluate mother's understanding of feeding plan.

Breast Pumping - Provide hospital-grade electric breast pump if pumping References: 27
- Assist with milk expression as soon as possible (ideally no later than $6 \mathrm{~h}$ after birth) if mother and infant are separated.

- Evaluate milk transfer and help mother hand express or pump after each feeding if milk transfer during breastfeeding is inadequate.

- Refer mother to a qualified lactation specialist if she has difficulty expressing milk or using breast pump.
- Explain the importance of early and frequent milk expression if one of the following is present: » Mother and infant are separated. » Breastfeeding is inadequate due to infant's prematurity or illness.

- Address the importance of reassuring/informing the mother that despite having to initially use a breast pump she can go on to successfully breastfeed.

- Teach techniques of milk expression: » Hand expression. " Mechanical milk pump use. » Hands-on pumping.

- Explain the importance of complete breast emptying at least 10-12 times per day to: » Reduce Feedback Inhibitor of Lactation (FIL). » Ensure adequate milk supply.

- Teach proper handling and storage of expressed milk.

\section{Reducing Risks} of Hyperbilirubinemia

References: 2,7 $20,28,29,30,31$ 32,33
- Identify known maternal/infant/family risk factors that add to increased risk of LPI.

- Assess adequacy of feeding (especially breastfeeding), voiding, and stooling.

- Evaluate for visible jaundice within first $24 \mathrm{~h}$. » If present, obtain either transcutaneous (TcB) or serum (TSB) bilirubin level.

- Obtain TcB or TSB at $24 \mathrm{~h}$ after birth or at the time of metabolic screening for all infants regardless of presence or absence of visual jaundice (visual assessment alone is not reliable).

- Plot bilirubin levels on hour-specific Bhutani Nomogram to determine risk category and intervention threshold(s) for infants $>35$ weeks GA. For infants $<35$ weeks GA, consult next-level perinatal care provider.

- Obtain repeat bilirubin level prior to transition/discharge to determine rate of rise.

- If rate of rise is $>0.5 \mathrm{mg} / \mathrm{dL} / \mathrm{h}$, consider initiating phototherapy.

- If bilirubin levels checked prior to transition/discharge are higher than threshold for age in hours, initiate phototherapy. » Provide phototherapy in mother's room, if possible. » Monitor repeat bilirubin levels per hospital protocol. » Transfer to higher level of care if infant does not respond to phototherapy in expected manner.

- Plan for repeat bilirubin testing within 24-48 h if indicated for infants transitioned/discharged prior to $72 \mathrm{~h}$ of age. Additional testing may be needed to coincide with peak bilirubin levels which may occur on days 5-7 in LPIs.

\section{Optimizing \\ - Assess parents' understanding of LPI brain immaturity} Neurologic Development

References: 34 and implications for apnea risks, feeding and sleeping behaviors, tone, and development.
- Explain LPI's increased risk for hyperbilirubinemia: » Delay in bilirubin metabolism and excretion. " Peak bilirubin levels at days 5-7 after birth. " Twice as likely to have significantly high bilirubin levels and more susceptible to bilirubin toxicity.

- Provide written and verbal information about jaundice, risks of kernicterus, and possible need for phototherapy to treat hyperbilirubinemia.

- Teach how to recognize signs and symptoms of hyperbilirubinemia and when to alert healthcare provider for immediate evaluation of infant.

- Stress importance of adequate feeding to minimize the risk of dehydration and hyperbilirubinemia.

- Stress importance of follow-up for all LPIs.

\section{SCREENING}

Newborn

\section{Screening}

References: 55, 56, $73,74,75$
- Ensure familiarity with requirements of individual state's newborn screening mandates (www2.aap.org/ healthtopics/newbornscreening.cfm).

- Document date and time of state-required newborn screening. » Screening should be done $24 \mathrm{~h}$ after feeding
- Explain immaturity of LPI's brain and central nervous system (CNS). » Fetal brain cortical volume increases by $50 \%$ between 34 and 40 weeks GA, with great increase in surface area.

- Review implications of immature brain for apnea risks, feeding and sleeping behaviors, tone, and development, including: » Apnea of prematurity and periodic breathing. " Poor coordination of suck/swallow/breathe and need for pacing if bottle feeding. » Increased sleep needs and need to wake for feeds. » Decreased muscle tone and need for positioning support for airway and feeding/swallowing.
- Explain reasons for newborn screening

- Stress importance of asking primary care provider about results of newborn screening.

- Stress importance of any follow-up that is indicated: " Date, time, and location of follow-up appointment. 
is initiated. » Document plan to repeat test if screening performed earlier. » Document results, if available.

- Report abnormal results or plans for repeat testing to primary care provider. » Document that intended recipient received information sent.

Hearing Perform hearing screen prior to transition/discharge.

References: 2 - Document hearing screening date and results.

- Make referral to audiology service if indicated.

- Explain reasons for hearing screening.

- Reinforce understanding of hearing screening procedure.

- Stress importance of any follow-up that is indicated: " Date, time, and location of follow-up appointment.

- Explain that screening does not always diagnose a hearing deficit and that the need for follow-up does not always mean that the infant is impaired.

\section{Anomalies \\ References: 93 \\ - Evaluate infant for congenital anomalies. \\ - Consider pulse oximetry screening for congenital heart defects per hospital protocol.}

\section{Maternal}

Screening

References: 36,37

$38,39,40,41,42$

- Review maternal blood type.

- Review prenatal lab results and risk factors. » Be aware of Centers for Disease Control and Prevention (CDC) recommendations for HIV screening and treatment.
- Review ingestion of illicit and prescription drugs or other substances during pregnancy and refer mother to drug or alcohol rehabilitation program, if indicated.

- Review use of prescription or herbal medications or supplements of concern, if identified.

- Review smoking history (present or past use). » Refer family members who smoke to smoking cessation program. » Encourage mothers who quit smoking during or just prior to pregnancy to avoid relapse (high risk during the postpartum period).

- Screen for psychiatric illness or perinatal mood disorders (including postpartum depression and post-traumatic stress disorder). » Parents separated from the infant at birth (e.g., due to cesarean delivery or NICU admission) are at higher risk for perinatal mood disorders. » Mothers of infants born prematurely are at increased risk for mood disorders in the first 6 months postpartum (three times higher than mothers of term infants). » Make referrals for treatment if indicated.

- Evaluate mother's understanding of any referrals made.
- Explain any physical or internal anomalies found.

- Stress importance of any follow-up that is indicated. " Date, time, and location of follow-up appointment.

- Provide referrals to smoking cessation, drug or alcohol treatment, psychiatric, or support services, if indicated.

- Explain risks of secondhand smoke exposure. » Stress importance of providing a smoke-free environment for all infants and children, especially those born prematurely. " Secondhand smoke exposure is associated with apnea, SIDS, behavior disorders, hyperactivity, oppositional defiant disorder, sleep abnormalities, and upper respiratory infections.

- Explain risks and benefits of prescription and herbal medications and supplements, if indicated. » Where medications are indicated, encourage use of medications compatible with breastfeeding, if possible. Reference LactMed at http://toxnet.nlm.nih.gov/cgi-bin/sis/ htmlgen?LACT.

- Provide information about the signs and symptoms of postpartum depression and post-traumatic stress disorder, and encourage parents to seek help if needed.

\section{SAFETY}

\begin{tabular}{ll}
\hline In-Hospital & - Model proper hand hygiene when handling baby or \\
Safety & feeding equipment. \\
References: 7 & - Model proper equipment, positioning, and monitoring \\
& of the newborn for bathing, diapering, and routine care. \\
& - Model safe sleeping practices when placing baby in bed.
\end{tabular}

- Teach importance of handwashing before handling baby or feeding equipment.

- Teach proper use of: » Bulb syringe to suction nares, if needed. » Thermometer to take auxiliary temperature.

- Teach about safe bathing procedures, bath temperature, and maintaining a neutral thermal environment during bathing and care.

- Stress importance of placing babies on their backs to sleep in hospital and at home.

SUPPORT

Staff Support - Assess adequacy of staff support for physicians, midwives, nurses, lactation and feeding specialists, social workers, occupational therapists, physical therapists, case managers, transition/discharge planners, and home health services, including: » Availability of staff to support level of services offered. " Staffing ratios. " Competencies and skills. » Availability of referral services.
- Explain roles of multidisciplinary staff.

- Provide case manager evaluation to initiate transition/ discharge planning process.

\footnotetext{
Family Support

- Assess adequacy of family support including: » Partner's presence, involvement, and coping. " Grandparents and/or friends.

- Provide social worker evaluation of special needs as indicated.
}
- Provide contact information for support resources as indicated.
- Reinforce potential challenges of caring for LPI at home and encourage use of any needed resources.

*When communicating with families and providing education as listed in the Family Education column, concepts should be shared in a manner appropriate for the needs of the family including those whose first language is not English. 


\section{TRANSITION TO OUTPATIENT CARE}

Transition of care involves a set of actions designed to ensure continuity of care from inpatient to outpatient healthcare providers. Planning for transition of care should begin at the time of admission and requires a coordinated, multidisciplinary approach. The term "transition of care" is preferred to the term "discharge planning" in order to emphasize the active and dynamic nature of this process.

Optimal transition of care relies on accountable providers who ensure that accurate and complete information is successfully communicated and documented. The accountable sending provider sends the appropriate documents to the receiving provider in a timely manner, verifies the receipt of the information by the intended receiving provider, clarifies the receiving provider's understanding of the information sent, documents the transaction, and resends information if not received by the intended recipient. The accountable receiving provider acknowledges having received the documents and asks any questions for clarification of the information contained therein, uses the information, and takes actions as indicated, ensuring continuity of the plan of care or services. $^{43}$

\begin{tabular}{|c|c|c|}
\hline \multicolumn{3}{|l|}{ STABILITY } \\
\hline $\begin{array}{l}\text { Feeding } \\
\text { References: } 2,18,23,25,50 \\
51,52,53,54,55,56,57,58 \\
59,60,61,62\end{array}$ & $\begin{array}{l}\text { - For breastfeeding infants: » Provide formal } \\
\text { assessment by breastfeeding specialist at least twice } \\
\text { before transition/discharge. » Provide prescription } \\
\text { for breast pump if indicated. } \\
\text { - For formula feeding infants: » Provide formal } \\
\text { assessment by feeding specialist if intake is } \\
\text { inadequate or weight loss is abnormal. } \\
\text { - For all infants: » Document adequate infant feeding } \\
\text { competency for at least } 24 \mathrm{~h} \text {. " Evaluate parents' } \\
\text { understanding of home feeding plan. }\end{array}$ & $\begin{array}{l}\text { - Provide written and verbal infant feeding } \\
\text { information: » Recognizing early hunger cues. } \\
\text { » Breastfeeding frequency and technique. } \\
\text { " Supplemental feeding only if indicated (review } \\
\text { indications, such as signs of dehydration). » Breast } \\
\text { pumping, hand expression, and milk storage. } \\
\text { " Formula mixing if indicated. » Assessing adequate } \\
\text { intake. » Knowing how many wet diapers and stools } \\
\text { to expect. ( } 3 \text { voids and } 3 \text { stools by day } 3,4 \text { voids and } \\
4 \text { stools by day } 4,6 \text { voids and } 4 \text { stools by day } 6 \text { and } \\
\text { thereafter). » Understanding significance of } \\
\text { decreased urine and stool output. } \\
\text { - Teach how to give Vitamin D drops; explain that } \\
\text { Vitamin D deficiency is widespread in pregnant and } \\
\text { breastfeeding mothers, leading to increased risk of } \\
\text { rickets in infants. } \\
\text { - Teach how to give supplemental iron; explain that } \\
\text { lack of iron transfer from mother (normally occurs in } \\
\text { the third trimester) leads to increased risk of infant } \\
\text { anemia. } \\
\text { - Provide detailed home feeding plan. } \\
\text { - Provide contact information for community } \\
\text { breastfeeding support. }\end{array}$ \\
\hline $\begin{array}{l}\text { Circumcision } \\
\text { References: } 70,71,72\end{array}$ & $\begin{array}{l}\text { - Monitor for at least } 2 \mathrm{~h} \text { after procedure to assess for } \\
\text { bleeding. } \\
\text { - Document parents' understanding of post- } \\
\text { circumcision care. }\end{array}$ & $\begin{array}{l}\text { - Explain and demonstrate post-circumcision care. } \\
\text { - Explain and demonstrate care of intact penis if infant } \\
\text { is not circumcised. }\end{array}$ \\
\hline Newborn Care & $\begin{array}{l}\text { - Assess parents' understanding about general } \\
\text { newborn care and issues specific to LPIs. }\end{array}$ & $\begin{array}{l}\text { - Provide written and verbal education about general } \\
\text { newborn care and issues specific to LPIs: » Bathing } \\
\text { and diaper changing. » Cleaning and caring for } \\
\text { umbilical cord. » Value of skin-to-skin holding. } \\
\text { » Need for increased clothing to keep warm when } \\
\text { not in skin-to-skin contact. }\end{array}$ \\
\hline $\begin{array}{l}\text { Developmental Care } \\
\text { References: } 45,46,47,48,49\end{array}$ & $\begin{array}{l}\text { - Assess parents' understanding about developmental } \\
\text { care of preterm/LPI. }\end{array}$ & $\begin{array}{l}\text { - Explain the differences between corrected } \\
\text { gestational age (GA) and chronological age. }\end{array}$ \\
\hline
\end{tabular}


HEALTHCARE TEAM

- Model recognition of and sensitivity to infant's behavioral cues.

\section{FAMILY EDUCATION*}

» Developmental milestone expectations are based on corrected GA rather than chronological age.

- Stress importance of close monitoring of corrected GA developmental milestones by primary care provider.

- Provide written and verbal education about developmental care of preterms (including LPI): » Need for protection from overstimulation. » Need for positional support if low muscle tone. » Normal sleep/wake cycles and need for extra sleep.

- Teach signs (behavioral cues) of stress and overstimulation, including: » Limb extension, finger or toe splaying. " Twitches or startles. " Arching or limpness. " Facial grimace or scowl. » Abrupt color changes. » Irregular breathing. » Gaze aversion. " Crying.

- Teach signs of relaxation and readiness for engagement, including: " Limb flexion, relaxed fingers and toes. " Smooth movements. " Rounded, flexed trunk and back. » Relaxed face and mouth. » Normal color. » Regular breathing. » Eyes open and engaged. » Quiet-alert state.

- Stress the importance of skin-to-skin holding for optimal brain development.

\section{SCREENING}

Newborn Screening

References: 55, 56, 73, 74,75
- Ensure familiarity with requirements of individual state's newborn screening mandates.

- Document date and time of state-required newborn screening. " Ensure that screening is be done $24 \mathrm{~h}$ after feeding is initiated. » Document plan to repeat test if screening performed earlier.

" Document results, if available.

- Report abnormal results or plans for repeat testing to primary care provider. » Document that intended recipient received information sent.
- Reinforce reasons for newborn screening.

- Stress importance of asking primary care provider about results of newborn screening tests.

- Stress importance of any follow-up that is indicated: » Date, time, and location of follow-up appointment.

\section{Hearing}

References: 2
- Review hearing screen test date and results.

- Make referral to audiology service if indicated.

- Reinforce understanding of hearing screening procedure.

- Stress importance of any follow-up that is indicated: » Date, time, and location of follow-up appointment.

- Explain that screening does not always diagnose a hearing deficit and that the need for follow-up does not always mean that the infant is impaired.

- Explain any physical or internal anomalies found.

- Stress importance of any follow-up that is indicated: " Date, time, and location of follow-up appointment.

- Consider pulse oximetry screening for congenital heart defects per hospital protocol. If screen is done, document results.

- Review maternal blood type, prenatal lab results, and risk factors.

- Review ingestion of illicit and prescription drugs or other substances during pregnancy and any referrals for drug or alcohol rehabilitation program.

- Review use of prescription or herbal medications or supplements of concern, if identified.

- Review smoking history (present or past use) " Refer family members who smoke to smoking cessation program. » Encourage mothers who quit smoking during or just prior to pregnancy to avoid relapse (high risk during the postpartum period).

- Screen for psychiatric illness or perinatal mood disorders (including postpartum depression and post-traumatic stress disorder). » Parents separated from the infant at birth (e.g., due to cesarean delivery or NICU admission) are at higher risk for perinatal mood disorders. » Mothers of infants born
- Provide referrals to smoking cessation, drug or alcohol treatment, psychiatric, or support services, if indicated.

- Explain risks of secondhand smoke exposure. " Stress importance of providing a smoke-free environment for all infants and children, especially those born prematurely. " Secondhand smoke exposure is associated with apnea, Sudden Infant Death Syndrome (SIDS), behavior disorders, hyperactivity, oppositional defiant disorder, sleep abnormalities, and upper respiratory infections.

- Explain risks and benefits of prescription and herbal medications and supplements, if indicated. " Where medications are indicated, encourage use of medications compatible with breastfeeding, if possible. Reference LactMed at http://toxnet. nlm.nih.gov/cgi-bin/sis/htmlgen?LACT.

- Provide information about the signs and symptoms of postpartum depression and post-traumatic 


\section{HEALTHCARE TEAM}

prematurely are at increased risk for mood disorders in the first 6 months postpartum (three times higher than mothers of term infants). » Make referrals for treatment if indicated.

- Evaluate mother's understanding of any referrals made.

Parent-Infant Bonding

References: 77
- Assess family, home, and social risk factors that may affect bonding.

- Assess signs of attachment: » Infant's ability to demonstrate cues. » Parents' ability to recognize and respond appropriately to infant's

cues.

\section{FAMILY EDUCATION*}

stress disorder and encourage parents to seek help if needed.
- Reinforce parents' understanding of infant cues.

- Encourage frequent and prolonged skin-to-skin contact with both parents.

SAFETY

Family Risk Factors

References: 41, 57, 76, 77
- Document screening done and referrals made for the following: " Drug or alcohol use in home. " Smokers in home. » Domestic violence. " Mental health issues. " Social services involvement.

- Evaluate parent's understanding of any referrals made.
- Provide written and verbal information about available support services, if indicated.
- Assess parents' knowledge of how to make the home environment safe for infants.

- See Tips and Tools, Safety for Your Child (www.healthychildren.org/English/tips-tools/Pages/ default.aspx).

- Document screening and referrals made for the following: » Adequate housing/shelter. » Utilities. » Phone. » Fire alarms. » Transportation.

- Document education about safe infant sleep practices provided.

Safe Sleep

References: 24, 94, 95, 96, 97, 98,99

- See Ages \& Stages, A Parent's Guide to Safe Sleep (www.healthychildren.org/English/ages-stages/ baby/sleep/pages/ A-Parents-Guide-to-SafeSleep.aspx)

Infection \& Immunizations References: 2, 18, 53, 54, 57, $78,79,80,81,82,83$

- Document education provided.

- Give hepatitis B vaccine prior to transition/discharge. " If parents defer until 2-month vaccine schedule or defer entirely, document the decision.

- Give respiratory syncytial virus (RSV) prophylaxis and recommendations for repeat dosing as indicated.

- See Talking with Parents about Vaccines for Infants (www.cdc.gov/vaccines/spec-grps/hcp/ conv-materials.htm\#talkpvi)

- Ensure parents have a car seat or assist them in procuring one.

- Ensure car seat testing is done in the same car seat infant will use after transition/discharge. » A trained professional should teach proper use of car seat.

- Arrange for a car bed if the infant fails the car seat test.

Shaken Baby Prevention - Provide shaken baby syndrome information and Education

References: 117 explanation using visual aids and document viewing prior to transition/discharge.

- Assess parents' understanding of when to call 911. Emergency Number

When To Call Primary Care Provider
- Assess parents' understanding of when to call primary care provider.
- Teach ways to make the home environment safe for infants.

- Stress importance of adequate shelter for infant.

- Provide written and verbal information about available support services, if indicated.

- Review family's plan for communication with and transportation to primary care provider for infant follow-up visits.

- Reinforce the LPI's increased risk for SIDS

- Provide written and verbal information about placing infant on his/her back to sleep and on tummy to play.

- Explain unsafe sleeping practices.

- Recommend use of pacifier after first month after birth.

- Review ways to reduce illness. " Wash hands, limit visitors, avoid crowds, protect against contact with sick people. » Breastfeed for as long as possible during the first year after birth or longer.

- Stress importance of infant immunizations.

- Stress importance of flu shots and pertussis boosters for family and care providers.

- Provide written and verbal information about RSV prophylaxis and prevention.

- Instruct parents to bring their own car seat in for testing.

- Provide written and verbal instruction on proper use of car seat: " Correct way to secure car seat in car. " Correct way to secure infant in car seat. » Age of transition to front-facing car seat

- Provide written and verbal instruction about risks of shaking baby.

- Teach ways to calm infant.

- Teach ways to cope with crying infant.

- Teach how to recognize life-threatening events and when to call 911, including: » Apnea. » Choking. " Difficulty breathing. » Cyanosis

- Teach CPR.

- Teach how to recognize signs of illness and when to call primary care provider, including: " Lethargy. » Fever, hypothermia. » Poor skin color. » Decreased 


\begin{tabular}{|c|c|c|}
\hline & & $\begin{array}{l}\text { urine output. » Abdominal distension. » Vomiting. } \\
\text { " Bloody stool. » Inconsolable infant. " Uncertainty } \\
\text { about significance of infant's symptoms. }\end{array}$ \\
\hline \multicolumn{3}{|l|}{ SUPPORT } \\
\hline Staff Support & $\begin{array}{l}\text { - Assess adequacy of staff support for physicians, } \\
\text { midwives, nurses, lactation and feeding specialists, } \\
\text { social workers, occupational therapists, physical } \\
\text { therapists, case managers, transition/discharge } \\
\text { planners, and home health services. " Availability of } \\
\text { staff to support level of services offered. " Staffing } \\
\text { ratios. " Competencies and skills. " Availability of } \\
\text { referral services. }\end{array}$ & - Explain roles of multidisciplinary staff. \\
\hline Family and Social Support & $\begin{array}{l}\text { - Evaluate support needs and address barriers to care: } \\
\text { " Family/Social support network. » Community- } \\
\text { based services (e.g., WIC, lactation support, social } \\
\text { services). » Home health care referral. » Ongoing } \\
\text { infant care education. } \\
\text { - Ask parents if they have any questions or concerns } \\
\text { that have not already been addressed. } \\
\text { - Provide a call-back number for general questions } \\
\text { that come up after when family is home. }\end{array}$ & $\begin{array}{l}\text { - Provide written and verbal information about } \\
\text { available resources, if indicated. } \\
\text { - Reinforce potential challenges of caring for LPI at } \\
\text { home and encourage use of needed resources. }\end{array}$ \\
\hline \multicolumn{3}{|l|}{ TRANSFER OF CARE } \\
\hline $\begin{array}{l}\text { Primary Care Provider } \\
\text { References: } 85,86\end{array}$ & $\begin{array}{l}\text { - Identify community primary care provider and } \\
\text { document name, address, phone, fax, and email } \\
\text { address. } \\
\text { - Document plan for first follow-up appointment. }\end{array}$ & $\begin{array}{l}\text { - Review name, place, time, and purpose of first } \\
\text { follow-up appointment. } \\
\text { - Stress importance of initial and subsequent follow- } \\
\text { up appointments. }\end{array}$ \\
\hline $\begin{array}{l}\text { Discharge Summary \& } \\
\text { Checklist } \\
\text { References: } 43,77\end{array}$ & $\begin{array}{l}\text { - Complete transition/discharge summary: » Maternal } \\
\text { history, prenatal lab results, labor and delivery } \\
\text { course. " Birth events, Apgar scores, measurements. } \\
\text { " Hospital course, lab results, procedures, } \\
\text { medications. " Immunizations given. » Feeding } \\
\text { history and detailed feeding plan. » Growth chart } \\
\text { with birth and transition/discharge weights. } \\
\text { " Follow-up appointments planned. } \\
\text { - Send copy of transition/discharge summary to } \\
\text { community primary care provider. » Document } \\
\text { acknowledgment that the intended recipient } \\
\text { received and understood the information sent. } \\
\text { " Resend information if not received. } \\
\text { - Give copy of transition/discharge summary to } \\
\text { parents (in person) and evaluate parents' } \\
\text { understanding of content. } \\
\text { - Evaluate and assist with transportation issue(s), } \\
\text { as needed. }\end{array}$ & $\begin{array}{l}\text { - Explain content of transition/discharge summary. } \\
\text { " Stress importance of bringing transition/discharge } \\
\text { summary to all follow-up appointments. } \\
\text { - Explain infant's growth curve, immunization record, } \\
\text { list of medications, feeding plan, and follow-up. } \\
\text { " Ensure parents understanding of information } \\
\text { explained. " Ask parents if they have any questions } \\
\text { or concerns that have not already been addressed. } \\
\text { " Provide a call-back number for general questions } \\
\text { that come up after the family is home. }\end{array}$ \\
\hline
\end{tabular}

*When communicating with families and providing education as listed in the Family Education column, concepts should be shared in a manner appropriate for the needs of the family including those whose first language is not English.

\section{SHORT-TERM FOLLOW-UP CARE}

Late preterm infants (LPIs) should be seen by their community primary care provider within 1-2 days after transition/ discharge from the hospital; the provider should assess the infant's continued stability, review screening results, ensure ongoing safety, and evaluate the adequacy of support systems. LPIs can appear deceptively vigorous on the first day or two after birth prior to transition/discharge. It is not unusual for morbidities common to LPIs to first appear a few days after transition/ discharge. If not detected and managed early, these can quickly escalate and lead to re-hospitalization, increased family stress, and even permanent disability and death. ${ }^{2}$

It is especially important that breastfeeding LPIs be seen within a day after transition/discharge because of the feeding challenges so prevalent in this population. Immature feeding patterns, such as uncoordinated suck/swallow/breathe, ineffective milk transfer, and increased sleepiness because of immature brain/central nervous system (CNS) development, may not be apparent until the mother's milk supply increases on postpartum days 2-5. Feeding failure, in both breastfed and formula-fed newborns, can be caused by other morbidities more common in LPIs, such as respiratory distress, cold stress, sepsis, hyperbilirubinemia, low muscle tone, and decreased stamina. Congenital heart disease and patent ductus arteriosis, also more common in LPIs, should be considered for any infant with feeding failure.

The community follow-up care provider should have received a copy of the transition/discharge summary from the in-hospital care provider prior to the initial follow-up visit. To guide evaluation, the follow-up care provider should carefully review maternal and infant history, as well as the infant's hospital course, on the first follow-up visit. Because LPIs have many needs 
and because it is critically important to assess carefully the issues of continued stability, screening, safety, and support, it may be necessary to schedule extra time for follow-up visits of LPIs. Short-term follow-up care should include weekly asse- ssments until the infant reaches 40 weeks of corrected gestational age (GA) (the infant's due date) or is clearly thriving. ${ }^{25}$ More frequent visits may be necessary if weight or bilirubin checks are indicated.

\begin{tabular}{|c|c|c|}
\hline & HEALTHCARE TEAM & FAMILY EDUCATION* \\
\hline \multicolumn{3}{|l|}{ STABILITY } \\
\hline $\begin{array}{l}\text { Respiratory Distress } \\
\text { References: } 87\end{array}$ & $\begin{array}{l}\text { - Assess infant for current signs of respiratory distress. } \\
\text { - Ask parents if infant has had any history of apnea, } \\
\text { cyanosis, or respiratory distress. }\end{array}$ & $\begin{array}{l}\text { Reinforce LPI's increased risk for apnea and } \\
\text { respiratory instability, especially when in car seat and } \\
\text { upright devices. }\end{array}$ \\
\hline $\begin{array}{l}\text { Sepsis } \\
\text { References: } 88\end{array}$ & $\begin{array}{l}\text { - Assess infant for current signs of sepsis. } \\
\text { - Ask parents about any recent symptoms of sepsis. } \\
\text { - Ask parents if the infant's care givers or any of the care } \\
\text { givers' family members have signs of illness. }\end{array}$ & $\begin{array}{l}\text { - Reinforce LPI's increased risk for sepsis and re- } \\
\text { hospitalization. } \\
\text { - Review ways to reduce illness: » Wash hands, limit } \\
\text { visitors, avoid crowds, protect against contact with } \\
\text { sick people. " Breastfeed for as long as possible } \\
\text { during the first year after birth or longer. } \\
\text { - Review signs and symptoms of sepsis: } \\
\text { » Difficulty in breathing or feeding, increased or } \\
\text { decreased temperature, decreased energy level. } \\
\text { - Review how to take infant's temperature. } \\
\text { - If temperature }>100.4^{\circ} \mathrm{F}\left(38^{\circ} \mathrm{C}\right) \text {, take infant to primary } \\
\text { care provider. }\end{array}$ \\
\hline $\begin{array}{l}\text { Weight Loss } \\
\text { References: 2, 25, 89, } 90\end{array}$ & $\begin{array}{l}\text { - Assess weight 1-2 days after hospital transition/discharge } \\
\text { using appropriate preterm growth curves and compare } \\
\text { with infant's transition/discharge weight. } \\
\text { In addition to weight loss, take into account the number } \\
\text { of wet diapers and stools when evaluating adequacy of } \\
\text { intake ( } 3 \text { voids and } 3 \text { stools by day 3, } 4 \text { voids and } 4 \text { stools } \\
\text { by day } 4,6 \text { voids and } 4 \text { stools by day } 6 \text { and thereafter). } \\
\text { - Evaluate feeding practices if weight loss greater than } \\
\text { appropriate for age. » Ask mother about any pain with } \\
\text { breastfeeding. » Do oral exam and check for } \\
\text { abnormalities, such as ankyloglossia, cleft palate, or thrush. } \\
\text { " Observe infant feeding (breast or bottle). » Modify } \\
\text { feeding and supplementation appropriately. » If unable to } \\
\text { observe infant feeding, immediately refer mother to } \\
\text { lactation consultant or feeding specialist. » Make } \\
\text { appointment for repeat infant weight check. }\end{array}$ & $\begin{array}{l}\text { - Reinforce LPI's increased risk for excessive weight loss. } \\
\text { - Review normal weight-loss parameters: » No more } \\
\text { than } 3 \% \text { per day or total of } 10 \% \text { loss. » Regained by } \\
14 \text { days after birth. } \\
\text { - Review and validate understanding of feeding plan. } \\
\text { " Explain need for supplementation of breastmilk if } \\
\text { infant has excessive weight loss. } \\
\text { " Explain need to prevent infant dehydration by } \\
\text { ensuring infant has adequate fluid intake. } \\
\text { - Stress importance of follow-up for weight check: } \\
\text { " Date, time, and location of follow-up appointment }\end{array}$ \\
\hline $\begin{array}{l}\text { Feeding } \\
\text { References: } 23\end{array}$ & $\begin{array}{l}\text { - Determine family understanding of post-discharge } \\
\text { feeding plan and assess adherence to plan (including } \\
\text { iron and Vitamin D supplementation). } \\
\text { - Assess current feeding practices, including type of milk, } \\
\text { length of time feeding, amount taken (if formula fed). } \\
\text { - Assess urine output, stool color, and frequency and } \\
\text { symptoms of gastroesophageal reflux disease (GERD), } \\
\text { colic, or oral aversion. } \\
\text { - Modify feeding and supplementation plan if indicated. } \\
\text { " Encourage pumping and supplementing with } \\
\text { expressed breastmilk if supplementation is needed for } \\
\text { breastfed infants. » Provide prescription for breast pump, } \\
\text { if indicated. » Supplement with formula only as last resort. } \\
\text { - Encourage and support breastfeeding. } \\
\text { " Congratulate mother about choosing to breastfeed. } \\
\text { » Ask about pain with breastfeeding or any other } \\
\text { concerns. » Observe breastfeeding if concerns or } \\
\text { pain are described by mother (evaluate for } \\
\text { ankyloglossia). » Make immediate referral to lactation } \\
\text { consultant if needed. }\end{array}$ & $\begin{array}{l}\text { - Reinforce LPI's increased risk for failure to thrive and } \\
\text { re-hospitalization: » Immature feeding skills. } \\
\text { " Ineffective sucking/swallowing. » Uncoordinated } \\
\text { suck/swallow/breathe; may not be noticed until after } \\
\text { increase in breastmilk supply. » Longer sleep cycles, } \\
\text { may need to wake for feedings. } \\
\text { - Review normal feeding frequencies: " 10-12 times/ } \\
\text { day for breastfeeding infants. " 8-10 times/day for } \\
\text { formula-fed infants. } \\
\text { - Review normal urine output and stool frequency and } \\
\text { color as indicators of adequate feeding intake (and } \\
\text { lack of normal urine/stool as signs of dehydration): } \\
\text { " At least } 6 \text { wet diapers/24 h by day } 5 \text { after birth. " At } \\
\text { least } 1 \text { yellow seedy stool daily by day } 4 \text { after birth. } \\
\text { - Review benefits of breastfeeding/breastmilk for all } \\
\text { infants and their mothers. } \\
\text { - Provide contact information for lactation specialist } \\
\text { and community breastfeeding support. }\end{array}$ \\
\hline $\begin{array}{l}\text { Hyperbilirubinemia } \\
\text { References: } 28,56,64 \\
66,91\end{array}$ & $\begin{array}{l}\text { - Assess infant for jaundice 1-2 days after transition/ } \\
\text { discharge. } \\
\text { - Assess for any feeding difficulties or dehydration, } \\
\text { especially if infant is breastfeeding exclusively. } \\
\text { - Follow-up maternal and infant blood type and Direct } \\
\text { Coombs tests if available. } \\
\text { - Review 24-h bilirubin level and repeated evaluation } \\
\text { done prior to transition/discharge. }\end{array}$ & $\begin{array}{l}\text { - Reinforce LPI's increased risk for jaundice requiring } \\
\text { hospitalization and/or phototherapy. " Stress } \\
\text { increased risk for kernicterus } \\
\text { - Review delayed peak in bilirubin levels for LPIs (at } \\
\text { days 5-7 after birth) and possible need for additional } \\
\text { testing to coincide with this peak. } \\
\text { - Review signs and symptoms of worsening } \\
\text { hyperbilirubinemia: » Deepening yellow skin and eye }\end{array}$ \\
\hline
\end{tabular}




\section{HEALTHCARE TEAM}

- If concerned about elevated bilirubin, obtain Total Serum Bilirubin (TSB) or Transcutaneous Bilirubin (TCB) level (visual assessment is not reliable).

- Arrange for repeat bilirubin check, home phototherapy with follow-up, or hospital admission, as indicated.

\section{FAMILY EDUCATION*}

color (visual assessment alone is not reliable). "Sleepiness and lethargy. " Decreased feeding. "Increased irritability with high-pitched cry.

- Stress critical importance of follow-up with primary care provider if infant has signs or symptoms of worsening jaundice.

- Explain that breastfed infants are at higher risk for jaundice and need close monitoring of feedings to reduce risk of hyperbilirubinemia. » Infant may need supplementation. » Expressed breastmilk is ideal first choice. ॥ If mother's own milk or donor human milk is not available, cow's-milk-based formula may be used for supplementation.

Circumcision - Assess circumcision site for healing.

- Review normal course of healing and care of circumcised penis.

- Review care of intact penis if infant is not circumcised.

Newborn Care

References: 2, 7
- Evaluate appropriateness of infant's clothing for warmth and general cleanliness.

- Evaluate evidence for proper care of umbilicus and diaper area.

- Assess parents' knowledge and skill regarding routine newborn care.

Developmental Care References: 45, 46, 47, 48,49
- Evaluate parents' level of understanding about the special developmental care needs of the LPI.
- Review parents' understanding of all routine newborn care procedures, e.g., taking temperatures, appropriate clothing, bathing, and diapering.
- Explain the differences between corrected gestational age (GA) and chronological age. " Developmental milestone expectations are based on corrected GA rather than chronological age.

- Stress importance of close monitoring of developmental milestones by primary care provider.

- Provide written and verbal education about developmental care of preterms (including LPI): » Need for protection from overstimulation. » Need for positional support if low muscle tone. » Normal sleep/wake cycles and need for extra sleep

- Teach signs (behavioral cues) of stress and overstimulation, including: » Limb extension, finger or toe splaying. » Twitches or startles. » Arching or limpness. " Facial grimace or scowl. " Abrupt color changes. » Irregular breathing. » Gaze aversion. " Crying.

- Teach signs of relaxation and readiness for engagement, including: " Limb flexion, relaxed fingers and toes. " Smooth movements. " Rounded, flexed trunk and back. » Relaxed face and mouth. » Normal color. » Regular breathing. " Eyes open and engaged. " Quiet-alert state.

- Stress the importance of skin-to-skin holding for optimal brain development.

SCREENING

Newborn Screening References: 55, 56, 73, 74,75
- Ensure familiarity with requirements of individual state's newborn screening mandates.

- Follow-up on state-specific newborn screening mandates as indicated.

- Make referral or follow-up plan, if indicated.
- Respond to parents' questions about newborn screening results.

- Explain any abnormalities found during newborn screening results.

- Stress importance of any follow-up that is indicated: " Date, time, location of follow-up appointment.

- Explain reason for BAER if ordered: » Vulnerability of hearing to high bilirubin levels. » Importance of normal hearing for speech development.

- Stress importance of following-up on any hearing screening ordered: » Date, time, and location of follow-up appointment.

Respond to any questions about infant's anomalies.

- Stress importance of any follow-up that is indicated » Date, time and location of follow-up appointment

\section{Anomalies}

References: 93
- Identify physical or internal anomalies requiring further assessment or follow-up care.

- Assess parents' understanding of anomalies if present.

- Make follow-up plan for family. 


\section{HEALTHCARE TEAM}

Maternal Screening

References: 36, 37, 38, 39, $40,41,42$
- Review maternal prenatal lab results and risk factors.

- Review ingestion of illicit and prescription drugs or other substances during pregnancy and referrals to drug or alcohol rehabilitation program.

- Review use of prescription or herbal medications or supplements of concern, if identified.

- Review smoking history (present or past use). » Refer family members who smoke to smoking cessation program. " Encourage mothers who quit smoking during or just prior to pregnancy to avoid relapse (high risk during the postpartum period).

- Screen for psychiatric illness or perinatal mood disorders (including postpartum depression and posttraumatic stress disorder). » Parents separated from the infant at birth (e.g., due to cesarean delivery or NICU admission) are at higher risk for perinatal mood disorders. " Mothers of infants born prematurely are at increased risk for mood disorders in the first 6 months postpartum (three times higher than mothers of term infants). " Make referrals for treatment if indicated.

- Evaluate mother's understanding of any referrals made.

\section{Parent-Infant Bonding} References: 77
- Assess family, home, and social risk factors that may affect bonding.

- Assess maternal health and parents' ability to cope with challenges of newborn care and monitoring that can affect healthy bonding.

- Assess signs of bonding and attachment: » Infant's ability to demonstrate cues. " Parents' ability to recognize and respond appropriately to infant's cues.
FAMILY EDUCATION*

- Provide referrals to smoking cessation, drug or alcohol treatment, psychiatric, or support services, if indicated.

- Explain risks of secondhand smoke exposure. "Stress importance of providing a smoke-free environment for all infants and children, especially those born prematurely. " Secondhand smoke exposure is associated with apnea, Sudden Infant Death Syndrome (SIDS), behavior disorders, hyperactivity, oppositional defiant disorder, sleep abnormalities, upper respiratory infections.

- Explain risks and benefits of prescription and herbal medications and supplements, if indicated. » Where medications are indicated, encourage use of medications compatible with breastfeeding, if possible. Reference LactMed at http:// toxnet.nlm.nih.gov/cgi-bin/sis/htmlgen?LACT.

- Provide information about postpartum depression and post-traumatic stress disorder and encourage parents to seek help if needed.

- Review increased risk for postpartum mood disorders in mothers of infants born prematurely: » Nearly three times higher risk during first 6 months postpartum.

- Review parents' understanding of infant cues.

- Encourage skin-to-skin contact of LPI with both parents.

- Encourage parents to verbalize feelings about caring for their LPI and challenges they face that may affect healthy bonding and attachment.

\section{SAFETY}

Family Risk Factors

References: 41, 57,

76,77
- Assess and address family risk factors and make referrals if needed: » Drug or alcohol use in home. "Smokers in home.

» Domestic violence. » Mental health issues. » Social services involvement. » Provide additional education as needed.

- Evaluate parents' understanding of any referrals made.

Home Environment - Assess and address parents' knowledge of how to make the home environment safe for infants. ॥ See Tips and Tools, Safety for Your Child (www.healthychildren.org/ English/tips-tools/Pages/default.aspx). » Provide additional education as needed.

- Document screening and referrals made for the following: " Adequate housing/shelter. » Utilities. » Phone. » Fire alarms. » Transportation.

- Assess and address parents' understanding of safe sleep practices. » Provide additional education as needed.

\section{Safe Sleep}

References: 24, 94, 95, 96,

97, 98, 99
- Provide verbal and written information about where to get professional and community support.

- Teach ways to make the home environment safe for infants.

- Stress importance of adequate shelter for infant.

- Provide written and verbal information about available support services, if indicated.

- Review family's plan for communication with and transportation to primary care provider for infant follow-up visits.

- Reinforce LPI's increased risk for SIDS.

- Provide written and verbal information about placing infant on his/her back to sleep and on tummy to play.

- Explain unsafe sleeping practices.

- Recommend use of pacifier after first month after birth.

Immunizations

References: 2, 18, 53, 54,

$57,78,79,80,81,82,83$
- Assess and address parents' views and understanding about importance of immunizations for infant and family members. » Provide additional education as needed.
- Reinforce importance of immunizations for infant: » Scheduled immunizations as recommended by American Academy of Pediatrics (AAP). » Flu shots during flu season. » Respiratory syncytial virus (RSV) prophylaxis as indicated.

- Stress importance of flu shots and pertussis boosters for family and care providers.
Car Seat Safety

References: 84
- Determine whether parents have an appropriate car seat and refer for help as needed. » Refer for assistance in obtaining appropriate car seat as needed.

- Assess and address parents' understanding of proper
- Review proper use of car seats: » Correct way to secure car seat in car. » Correct way to secure infant in car seat » Age of transition to front-facing car seat. 


\begin{tabular}{|c|c|c|}
\hline & HEALTHCARE TEAM & FAMILY EDUCATION* \\
\hline & \multicolumn{2}{|l|}{$\begin{array}{l}\text { use of car seats. » Provide additional education/training } \\
\text { in proper car seat use as needed. }\end{array}$} \\
\hline $\begin{array}{l}\text { Shaken Baby } \\
\text { Prevention Education } \\
\text { References: } 117\end{array}$ & $\begin{array}{l}\text { - Assess and address parents' understanding of risks of } \\
\text { shaking baby. " Provide additional education as needed. } \\
\text { - Assess and address parents' knowledge of ways to calm } \\
\text { infants and cope with infant crying. " Provide } \\
\text { additional education as needed. } \\
\text { - Assess and address parents' coping and stress levels as } \\
\text { risks for shaken baby syndrome. " Provide additional } \\
\text { education as needed. }\end{array}$ & $\begin{array}{l}\text { - Review risks of shaking any baby. } \\
\text { - Review ways to calm crying infants. } \\
\text { - Review ways to cope with infant crying. } \\
\text { - Provide information about community or professional } \\
\text { resources as needed for support. }\end{array}$ \\
\hline $\begin{array}{l}\text { When To Call } 911 \text { or } \\
\text { Local Emergency } \\
\text { Number }\end{array}$ & $\begin{array}{l}\text { - Assess and address parents' understanding of when to } \\
\text { call 911. » Provide additional education as needed. }\end{array}$ & $\begin{array}{l}\text { - Review how to recognize life-threatening events and } \\
\text { when to call 911, including: » Apnea. » Choking. } \\
\text { " Difficulty breathing. » Cyanosis. } \\
\text { - Review CPR. }\end{array}$ \\
\hline $\begin{array}{l}\text { When To Call Primary } \\
\text { Care Provider }\end{array}$ & $\begin{array}{l}\text { - Assess and address parents' understanding of when to } \\
\text { call a primary care provider for urgent evaluation of } \\
\text { infant. } \\
\text { » Provide additional education as needed. }\end{array}$ & $\begin{array}{l}\text { - Teach how to recognize signs of illness and when to } \\
\text { call primary care provider, including: } \\
\text { " Lethargy. " Fever, hypothermia. " Poor skin color. } \\
\text { " Decreased urine output. " Abdominal distension. } \\
\text { " Vomiting. " Bloody stool. } \\
\text { " Inconsolable infant. " Uncertainty about } \\
\text { significance of infant's symptoms. }\end{array}$ \\
\hline \multicolumn{3}{|l|}{ SUPPORT } \\
\hline $\begin{array}{l}\text { Family and Social } \\
\text { Support }\end{array}$ & $\begin{array}{l}\text { - Evaluate support needs and address barriers to care: } \\
\text { " Family/Social support network. " Community-based } \\
\text { services (e.g., WIC, lactation support, social services). } \\
\text { " Home health care referral. » Ongoing infant care } \\
\text { education } \\
\text { - Ask parents if they have any questions or concerns that } \\
\text { have not already been addressed. } \\
\text { - Provide a call-back number for general questions that } \\
\text { come up after when family is home. }\end{array}$ & $\begin{array}{l}\text { - Provide verbal and written information about where } \\
\text { to find support if needed. } \\
\text { - Reinforce potential challenges of caring for LPI at } \\
\text { home and encourage utilization of resources as } \\
\text { needed. }\end{array}$ \\
\hline
\end{tabular}

\section{LONG-TERM FOLLOW-UP CARE}

There is no recognized endpoint to long-term follow-up care of late preterm infants (LPIs). Because research has documented increased morbidities for LPIs during infancy, childhood, adolescence, and through adulthood, follow-up care must begin at birth and continue, with varying degrees of surveillance and reflecting individual needs, throughout the lifespan.

The importance of establishing a medical home for each LPI cannot be overemphasized. A medical home is necessary to ensure that appropriate screening and assessments are completed, referrals are made, continuity of care is coordinated and implemented by a multidisciplinary team, and duplication of services is avoided. At each follow-up visit the continued stability, screening, safety, and support of LPIs and their families should be assessed.

Ongoing follow-up care should continue to be culturally, developmentally, and age-appropriate, taking into account families' preferences and ensuring that parents are active participants in making informed decisions about follow-up testing and therapeutic interventions. Communication should occur and education should be provided in ways that are appropriate for families with limited or no English proficiency or health literacy and in ways that are developmentally appropriate for the target audience (e.g., teen parents).

If an LPI was transitioned to a higher level of care during the initial or subsequent hospitalizations, or if the mother and infant were separated at birth, both mother and father/partner should be monitored closely for signs of postpartum depression and posttraumatic stress disorder during the postpartum period and the first year of the infant's life. Because optimal infant development is so influenced by the mental health of the infant's primary caregivers, especially that of the mother, referrals should be made for professional help and community support whenever indicated. $^{100,101,102,103}$

\section{HEALTHCARE TEAM}

FAMILY EDUCATION*

STABILITY

\section{Growth}

References: 52, 104
- Monitor growth parameters (weight, length, and head circumference) at each well-child visit.

- Consider need for fortification or supplementation of either breastmilk or formula if infant is failing to thrive per appropriate preterm
- Assess parents' knowledge and reinforce importance of good nutrition.

- Reinforce the health benefits of exclusive breastfeeding with appropriate fortification or supplementation if indicated, until 6 months of 


\section{HEALTHCARE TEAM}

growth curves. " Assess both volume of intake and also caloric density of feeds when planning fortification or supplementation. " Reassess at each visit to determine continued need for fortification or supplementation to maintain normal growth. " Encourage fortification/ supplementation in ways that encourage suckling at the breast, if possible, such as higher calorie transitional formula given at separate feeds from breastfeeding. This is preferable to giving fortified expressed milk in a bottle at each feeding, which discourages feeding at the breast.

- Recommend introducing solid foods no earlier than 6 months corrected gestational age (GA) and when infant demonstrates developmental readiness.

Respiratory Illness

References: 105, 118
- Assess parents' understanding of ways to reduce upper respiratory infections throughout the first few years after birth.

- Ask about signs or symptoms of asthma.

\section{FAMILY EDUCATION*}

age. » Decreased incidence in gastrointestinal illnesses. » Possible delay in onset of eczema allergies. " No decrease in growth.

- Provide verbal and printed information about appropriate introduction of healthy solid foods after 6 months of age. " Assess parents' ability to choose and obtain healthy baby food. " Encourage continued breastfeeding until at least 1 year of age or longer in addition to solid foods.

- Reinforce the importance of continuing to monitor growth.
- Reinforce increased LPI's risk for asthma, respiratory infection and re-hospitalization during the first year after birth: » Respiratory syncytial virus (RSV) is the most common infectious etiology. " High morbidity is similar to that of extremely preterm infants if admitted to the PICU.

- Review ways to avoid respiratory illness: » Keep immunizations current. » Avoid crowds and contact with sick people. » Careful and consistent handwashing. » Protect from secondhand smoke. » Breastfeed for as long as possible during the first year after birth or longer. » Maintain good nutrition on a long-term basis. " RSV prophylaxis as indicated.

\section{SCREENING}

\section{Sensory Screening}

References: 105, 106, 107, 108
- Evaluate for sensory impairments, including hearing, sight, and sensory integration.

- Follow-up brainstem auditory evoked response (BAER) results if referral had been made.

- Monitor for syndrome of auditory neuropathy/ auditory dyssynchrony (normal otoacoustic emission (OAE) with abnormal auditory brain response $(A B R))$.

- Provide education about increased risk for sensory impairments: » Hearing impairment or deafness. " Visual impairment or blindness. " Disorders of sensory integration. " Auditory and visual processing delay.

- Stress importance of hearing or vision follow-up. " Review date, time, and location of follow-up appointments.

- Stress importance of alerting primary care provider of any concerns about hearing, vision, or speech.

\section{Developmental Screening}

References: 2, 4, 10, 47, 75, 77, 85, $106,109,110,111,112,113,114$, 115,116

- Perform regular developmental screening using valid and reliable assessment tools, such as: " Modified Checklist for Autism in Toddlers (MCHAT). » American Academy of Pediatrics' (AAP) Bright Futures, including Pediatric Symptom Checklist (ages 4 years and up). » Brief Infant Toddler Social Emotional Assessment (BITSEA), for age 12-36 months; parent can fill out in 7-10 min

- See the AAP's websites for more tools (www.medicalhomeinfo.org) and (www.aap.org/ sections/dbpeds).

- Make referrals as indicated.

Behavioral Screening

References: 77, 86, 106
- Ask parents about any signs of behavioral or emotional disturbances in toddler or child.

- Assess family's support system and coping abilities.

- Make referrals as indicated.
- Teach about LPI's increased risk for developmental delays: „ Psychomotor delay. " Cerebral palsy. " Cognitive delay. " Delay in school readiness. » Increased need for special educational services. " Increased disability (74\% of total disability associated with preterm birth).

- Stress importance of developmental follow-up. " Review date, time, and location of follow-up appointments.
- Educate about LPI's increased risk for behavioral and emotional disturbances: » Attention disorders. " Hyperactivity. » Internalizing behaviors. » Autism. " Schizophrenia.

- Stress importance of alerting primary care provider regarding abnormal behaviors.

\section{Maternal Screening}

References: 36, 37, 38, 39, 40, 41,42
- Review ingestion of illicit and prescription drugs or other substances during pregnancy and refer mother to drug or alcohol rehabilitation program, if indicated.

- Review use of prescription or herbal medications or supplements of concern, if identified.

- Review smoking history (present or past use). " Refer family members who smoke to smoking
- Provide referrals to smoking cessation, drug or alcohol treatment, psychiatric, or support services, if indicated.

- Explain risks of secondhand smoke exposure. " Stress importance of providing a smoke-free environment for all infants and children, especially those born prematurely. " Secondhand smoke exposure is associated with apnea, Sudden Infant 


\begin{tabular}{|c|c|c|}
\hline & HEALTHCARE TEAM & FAMILY EDUCATION* \\
\hline & $\begin{array}{l}\text { cessation program. » Encourage mothers who quit } \\
\text { smoking during or just prior to pregnancy to avoid } \\
\text { relapse (high risk during the postpartum period). } \\
\text { - Screen for psychiatric illness or perinatal mood } \\
\text { disorders (including postpartum depression and } \\
\text { post-traumatic stress disorder). » Parents } \\
\text { separated from the infant at birth (e.g., due to } \\
\text { cesarean delivery or NICU admission) are at } \\
\text { higher risk for perinatal mood disorders. } \\
\text { » Mothers of infants born prematurely are at } \\
\text { increased risk for mood disorders in the first } \\
6 \text { months postpartum (three times higher than } \\
\text { mothers of term infants). » Make referrals for } \\
\text { treatment if indicated. } \\
\text { - Evaluate mother's understanding of any referrals } \\
\text { made. }\end{array}$ & $\begin{array}{l}\text { Death Syndrome (SIDS), behavior disorders, } \\
\text { hyperactivity, oppositional defiant disorder, } \\
\text { sleep abnormalities, and upper respiratory } \\
\text { infections. } \\
\text { - Explain risks and benefits of prescription and } \\
\text { herbal medications and supplements, if } \\
\text { indicated. » Where medications are indicated, } \\
\text { encourage use of medications compatible with } \\
\text { breastfeeding, if possible. Reference LactMed at } \\
\text { http://toxnet.nlm.nih.gov/cgi-bin/sis/ } \\
\text { htmlgen?LACT. } \\
\text { - Provide information about postpartum } \\
\text { depression and post-traumatic stress disorder } \\
\text { and encourage parents to seek help if needed. } \\
\text { - Provide contact information for local professional } \\
\text { and community resources as appropriate to } \\
\text { provide assistance for parenting support, } \\
\text { substance abuse, domestic violence, and mental } \\
\text { health issues }\end{array}$ \\
\hline $\begin{array}{l}\text { Family Risk Factors } \\
\text { References: } 41,57,76,77\end{array}$ & $\begin{array}{l}\text { - Assess family risk factors and make referrals if } \\
\text { needed: » Drug or alcohol use in home. } \\
\text { "Smokers in home. » Domestic violence. } \\
\text { " Mental health issues. » Social services } \\
\text { involvement. } \\
\text { - Evaluate parents' understanding of any referrals } \\
\text { made. }\end{array}$ & $\begin{array}{l}\text { Provide verbal and written information about } \\
\text { where to get professional and community } \\
\text { support. }\end{array}$ \\
\hline Developmental Risk Factors & $\begin{array}{l}\text { - Assess for fine and gross motor development } \\
\text { and behaviors that may lead to potential safety } \\
\text { risks. }\end{array}$ & $\begin{array}{l}\text { - Review LPI's increased risk for fine and gross } \\
\text { motor development and behaviors that may lead } \\
\text { to potential safety risks: » Hyperactivity. » Seizure } \\
\text { disorder. }\end{array}$ \\
\hline Family Support & $\begin{array}{l}\text { - Assess adequacy of family's support system. } \\
\text { - Identify family's support needs: » Parent support } \\
\text { groups for specific disabilities. » State parent-to- } \\
\text { parent groups or other parenting support } \\
\text { groups. » State parent training and information } \\
\text { - Ask parents if they have any questions or } \\
\text { concerns that have not already been addressed. } \\
\text { - Provide a call-back number for general questions } \\
\text { that come up when family is home. }\end{array}$ & $\begin{array}{l}\text { - Reinforce increased risk of need for specialized } \\
\text { family support due to special needs of infants } \\
\text { born prematurely. } \\
\text { - Provide verbal and written information about } \\
\text { how to find state and community resources for } \\
\text { families of infants born prematurely. }\end{array}$ \\
\hline
\end{tabular}

*When communicating with families and providing education as listed in the Family Education column, concepts should be shared in a manner appropriate for the needs of the family including those whose first language is not English.

\section{CONFLICT OF INTEREST}

The Steering Committee members disclosed no relevant financial relationships that might create a conflict of interest in the development of the Multidisciplinary Guidelines for the Care of Late Preterm Infants. The development of the guidelines and funding for this supplement were supported through sponsorships from Philips Mother \& Child Care and GE Healthcare Maternal-Infant Care. These organizations had no input or editing rights to the content included in the guidelines.

\section{ACKNOWLEDGEMENTS}

The Steering Committee gratefully acknowledges Amy Akers for her exceptional skills in communication, coordination and creativity, without which this project would have been nothing more than a great idea that never reached fruition.

\section{REFERENCES}

1 Raju TN, Higgins RD, Stark AR, Leveno KJ. Optimizing care and outcome for late-preterm (near-term) infants: a summary of the workshop sponsored by the 
National Institute of Child Health and Human Development. Pediatrics 2006; 118 1207-1214.

2 Engle WA, Tomashek KM, Wallman C. Committee on Fetus and Newborn, American Academy of Pediatrics. 'Late-preterm' infants: a population at risk. Pediatrics 2007; 120: 1390-1401.

3 Spitzer AR, Ellsbury DL, Handler D, Clark RH. The Pediatrix BabySteps ${ }^{\circledR}$ Data Warehouse and the Pediatrix QualitySteps improvement project system - tools for 'meaningful use' in continuous quality improvement. Clin Perinatol 2010; 37: 49-70.

4 McCormick MC, Escobar GJ, Zheng Z, Richardson DK. Place of birth and variations in management of late preterm ("near-term") infants. Semin Perinatol 2006; 30: 44-47.

5 Escobar GJ, Clark RH, Greene JD. Short-term outcomes of infants born at 35 and 36 weeks gestation: we need to ask more questions. Semin Perinatol 2006; 30: 28-33.

6 Shapiro-Mendoza CK, Tomashek KM, Kotelchuck M, Barfield W, Nannini A, Weiss $\mathrm{J}$ et al. Effect of late-preterm birth and maternal medical conditions on newborn morbidity risk. Pediatrics 2008; 121: e223-232.

7 Association of Women's Health, Obstetric, and Neonatal Nurses (AWHONN). Assessment and Care of the Late Preterm Infant Evidence-Based Clinical Practice Guidelines. AWHONN: Washington, DC, 2010.

8 Britton JR. The transition to extrauterine life and disorders of transition. Clin Perinatol 1998; 25: 271-294.

9 Council of International Neonatal Nurses. Position Statement on Care of the LatePreterm Infant http://www.napnap.org/Files/Position_Stat_Late_Preterm(2).pdf. Accessed June 18, 2012.

10 Ludington-Hoe SM, Anderson GC, Swinth JY, Thompson C, Hadeed AJ. Randomized controlled trial of kangaroo care: cardiorespiratory and thermal effects on healthy preterm infants. Neonatal Netw 2004; 23: 39-48.

11 Bergman NJ, Linley LL, Fawcus SR. Randomized controlled trial of skin-to-skin contact from birth versus conventional incubator for physiological stabilization in 1200- to 2199-gram newborns. Acta Paediatr 2004; 93: 779-785.

12 Baby-Friendly Hospital Initiative. Baby-Friendly USA. Baby-Friendly USA, Inc Sandwich, MA, 2010

13 American College of Obstetricians and Gynecologists (ACOG). Committee on Obstetric Practice. ACOG Committee Opinion No. 404 April 2008. Late-preterm infants. Obstet Gynecol 2008; 111: 1029-1032.

14 Lemons JAL, Lockwood CJ. 466 American Academy of Pediatrics and ACOG 2007.

15 Ballard JL, Khoury JC, Wedig K, Wang L, Eilers-Walsman BL, Lipp R. New Ballard Score, expanded to include extremely premature infants. J Pediatr 1991; 119: 417-423.

16 Garcia Bartels N, Mieczko A, Schink T, Proquitté H, Wauer RR, Blume-Peytavi U. Influence of bathing or washing on skin barrier function in newborns during the first four weeks of life. Skin Pharmacol Physiol 2009; 22: 248-257.

17 Oklahoma Infant Alliance. Caring for the Late Preterm Infant: A Clinical Practice Guideline. 2010 http://oklahomainfantalliance.org/uploads/LPI_Clinical_Practice_Guideline_Sample.pdf. Accessed June 18, 2012.

18 Darcy AE. Complications of the late preterm infant. J Perinat Neonatal Nurs 2009; 23: 78-86.

19 Moolenaar RLE. Vol. 59 Morbidity and Mortality Weekly Report (ed Centers for Disease Control and Prevention Department of Health and Human Services) 34 (Center for Disease Control 2010.

20 Wang ML, Dorer DJ, Fleming MP, Catlin EA. Clinical outcomes of near-term infants. Pediatrics 2004; 114: 372-376.

21 Adamkin $\mathrm{DH}$. and the Committee on Fetus and Newborn. Postnatal glucose homeostasis in late-preterm and term infants. Pediatrics 2011; 127: 575-579.

22 Hake-Brooks SJ, Anderson GC. Kangaroo care and breastfeeding of motherpreterm infant dyads $0-18$ months: a randomized, controlled trial. Neonatal Netw 2008; 27: 151-159.

23 Walker M. Breastfeeding the late preterm infant. J Obstet Gynecol Neonatal Nurs 2008; 37: 692-701.

24 Mayes G, Timms L. Dummies, breastfeeding and prevention of sudden infant death syndrome (SIDS). Community Pract 2011; 84: 14.

25 The Academy of Breastfeeding Medicine. ABM Clinical Protocol No. 10: Breastfeeding the late preterm infant (34 0/7 to 36 6/7 weeks gestation). Breastfeed Med 2011; 6: 151-156.

26 Meier P, Brown LP, Hurst NM, Spatz D, Engstrom JL, Borucki LC et al. Nipple shields for preterm infants: effect on milk transfer and duration of breastfeeding. $J$ Hum Lact 2000; 16: 106-114.

27 Morton J, Hall JY, Wong RJ, Thairu L, Benitz WE, Rhine WD. Combining hand techniques with electric pumping increases milk production in mothers of preterm infants. J Perinatol 2009; 29: 757-764.

28 Sarici SU, Serdar MA, Korkmaz A, Erdem G, Oran O, Tekinalp G et al. Incidence, course, and prediction of hyperbilirubinemia in near-term and term newborns. Pediatrics 2004; 113: 775-780.

29 Bhutani VK, Johnson L, Sivieri EM. Predictive ability of a predischarge hourspecific serum bilirubin for subsequent significant hyperbilirubinemia in healthy term and near-term newborns. Pediatrics 1999; 103: 6-14.
30 Bhutani VK. Combining clinical risk factors with serum bilirubin levels to predict hyperbilirubinemia in newborns. J Pediatr 2005; 147: 123-124.

31 Adamkin $\mathrm{DH}$. Late preterm infants: severe hyperbilirubinemia and postnatal glucose homeostasis. J Perinatol 2009; 29(Suppl 2): S12-17.

32 American Academy of Pediatrics Subcommittee on Hyperbilirubinemia. Management of hyperbilirubinemia in the newborn infant 35 or more weeks of gestation. Pediatrics 2004; 114: 297-316.

33 Halpern BG. Mitchell. Los Angeles, CA: Perinatal Advisory Council: Leadership, 47 and Consultation 2006

34 Adams-Chapman I. Long-term neurologic outcome of infants born by cesarean section. Clin Perinatol 2008; 35: 437-454.

35 Ewer AK, Middleton LJ, Furmston AT, Bhoyar A, Daniels JP, Thangaratinam S, Deeks JJ, Kha KS et al. Pulse oximetry screening for congenital heart defects in newborn infants (PulseOx): a test accuracy study. Lancet 2011; 378: 785-794.

36 Services, U. S. D. o. H. a. Hed National Center for Chronic Disease Prevention and Health Promotion Coordinating Center for Health Promotion, Office on Smoking and Health) (Centers for Disease Control and Prevention, Atlanta, GA 2007.

37 Fang WL, Goldstein AO, Butzen AY, Hartsock SA, Hartmann KE, Helton M et al. Smoking cessation in pregnancy: a review of postpartum relapse prevention strategies. J Am Board Fam Pract 2004; 17: 264-275.

38 U.S. National Library of Medicine, National Institutes of Health, Health and Human Services. TOXNET Toxicology Data Network: Drugs and Lactation Database (LactMed) Available at http://toxnet.nlm.nih.gov/cgi-bin/sis/htmlgen?LACT Accessed June 27, 2012.

39 Vigod SN, Villegas L, Dennis CL, Ross LE. Prevalence and risk factors for postpartum depression among women with preterm and low-birth-weight infants: a systematic review. BJOG 2010; 117: 540-550.

40 Brandon DH, Tully KP, Silva SG, Malcolm WF, Murtha AP, Turner BS, HolditchDavis $\mathrm{D}$ et al. Emotional responses of mothers of late-preterm and term infants. JOGNN 2011; 40: 719-31.

41 Voegtline KM, Stifter CA. The Family Life Project Investigators. Late-preterm birth maternal symptomatology, and infant negativity. Infant Behav Dev 2010; 33(4): 545-54.

42 Zanardo V, Gambina I, Begley C, Litta P, Cosmi E, Giustardi A et al. Psychological distress and early lactation performance in mothers of late preterm infants. Early Human Dev 2011; 87(4): 321-3.

43 National Transitions of Care Coalition Measures Work Group. Transitions of Care Measures 2008http://www.ntocc.org/Portals/0/TransitionsOfCare_Measurespdf. Accessed June 18, 2012

44 Newborns' and Mothers' Health Protection Act of 1996 http://www.dol.gov/ ebsa/newsroom/fsnmhafs.html.

45 American Academy of Pediatrics Committee on Children with Disabilities. Developmental surveillance and screening of infants and young children. Pediatrics 2001; 108: 192-196.

46 Als H. Developmental care in the newborn intensive care unit. Curr Opin Pediatr 1998; 10: 138-142.

47 Chyi LJ, Lee HC, Hintz SR, Gould JB, Sutcliffe TL. School outcomes of late preterm infants: special needs and challenges for infants born at 32 to 36 weeks gestation. J Pediatr 2008; 153: 25-31.

48 Cooley WC, McAllister JW, Sherrieb K, Kuhlthau K. Improved outcomes associated with medical home implementation in pediatric primary care. Pediatrics 2009; 124: 358-364.

49 Als H. Toward a synactive theory of development: promise for the assessment and support of infant individuality. Infant Ment Health J 1982; 3: 229-243.

50 Adamkin DH. Feeding problems in the late preterm infant. Clin Perinatol 2006; 33: 831-837.

51 Cleaveland K. Feeding challenges in the late preterm infant. Neonatal Netw 2010; 29: 37-41.

52 Fein SB, Labiner-Wolfe J, Shealy KR, Li R, Chen J, Grummer-Strawn LM. Infant Feeding Practices Study II: study methods. Pediatrics 2008; 122(Suppl 2): S28-35.

53 Goyal NK, Fager C, Lorch SA. Adherence to discharge guidelines for latepreterm newborns. Pediatrics 2011; 128: 62-71.

54 Kalyoncu O, Aygun C, Cetinoglu E, Kucukoduk S. Neonatal morbidity and mortality of late-preterm babies. J Matern Fetal Neonat Med 201; 23: 607-612.

55 Raju TN. Late-preterm births: challenges and opportunities. Pediatrics 2008; 121 : 402-403.

56 Tomashek KM, Shapiro-Mendoza CK, Weiss J, Kotelchuk M, Barfield W, Evans $S$ et al. Early discharge among late preterm and term newborns and risk of neonatal morbidity. Semin Perinatol 2006; 30: 61-68.

57 Verklan MT. So, he's a little premature...what's the big deal? Crit Care Nurs Clin North Am 2009; 21: 149-161.

58 Dee DL, Sharma AJ, Cogswell ME, Grummer-Strawn LM, Fein SB, Scanlon KS. Sources of supplemental iron among breastfed infants during the first year of life. Pediatrics 2008; 122(Suppl 2): S98-104.

59 Backstrom MC, Aine L, Maki R, Kuusela AL, Sievanen $H$, Koivisto AM et al. Maturation of primary and permanent teeth in preterm infants. Arch Dis Child Fetal Neonatal Ed, 2000; 83: F104-108. 
60 Bosley AR, Verrier-Jones ER, Campbell MJ. Aetiological factors in rickets of prematurity. Arch Dis Child 1980; 55: 683-686.

61 Giapros VI, Schiza V, Challa AS, Cholevas VK, Theocharis PD, Kolios G et al. Vitamin $D$ and parathormone levels of late-preterm formula fed infants during the first year of life. Eur J Clin Nutr 2012; 66: 224-230.

62 Jain BK. Vitamin requirements of very low birth weight infants: a review. Indian J Matern Child Health 1994; 5: 46-49.

63 Bhutani VK, Johnson L. Kernicterus in late preterm infants cared for as term healthy infants. Semin Perinatol 2006; 30: 89-97.

64 Burgos AE, Schmitt SK, Stevenson DK, Phibbs CS. Readmission for neonatal jaundice in California, 1991-2000: trends and implications. Pediatrics 2008; 121: e864-869.

65 Kaplan M, Merlob P, Regev R. Israel guidelines for the management of neonatal hyperbilirubinemia and prevention of kernicterus. J Perinatol 2008; 28: 389-397.

66 Keren R, Tremont K, Luan X, Cnaan A. Visual assessment of jaundice in term and late preterm infants.. Arch Dis Child Fetal Neonatal Ed 2009; 94: F317-322.

67 Watchko JF. Hyperbilirubinemia and bilirubin toxicity in the late preterm infant. Clin Perinatol 2006; 33: 839-852.

68 Watchko JF. Hyperbilirubinemia in African American neonates: clinical issues and current challenges. Semin Fetal Neonatal Med 2010; 15: 176-182.

69 Yu ZB, Dong XY, Han SP, Chen YL, Qiu YF, Sha L et al. Transcutaneous bilirubin nomogram for predicting neonatal hyperbilirubinemia in healthy term and latepreterm Chinese infants. Eur J Pediatr 2011; 170: 185-191.

70 Bhat BA, Menon K, Jimenez R. Early discharge after neonatal circumcision. Ann Saudi Med 2001; 21: 133-134.

71 Narchi H, Kulaylat N. Neonatal circumcision: when can infants reliably be expected to void? Pediatrics 1998; 102: 150-152.

72 Perlmutter DF, Lawrence JM, Krauss AN, Auld PA. Voiding after neonatal circumcision. Pediatrics 1995; 96: 1111-1112.

73 Romeo DM, Ricci D, Brogna C, Cilauro S, Lombardo ME, Romeo MG et al. Neurological examination of late-preterm infants at term age. Eur $J$ Paediatr Neurol 2011; 15: 353-360.

74 Saluja S, Agarwal A, Kler N, Amin S. Auditory neuropathy spectrum disorder in late preterm and term infants with severe jaundice. Int J Pediatr Otorhinolaryngol 2010; 74: 1292-1297.

75 Woythaler MA, McCormick MC, Smith VC. Late preterm infants have worse 24-month neurodevelopmental outcomes than term infants. Pediatrics 2011; 127: e622-629.

76 Shapiro-Mendoza CK, Tomashek K, Kotelchuk M, Barfield W, Weiss J, Evans S. Risk factors for neonatal morbidity and mortality among "healthy," late preterm newborns. Semin Perinatol 2006; 30: 54-60.

77 Talge NM, Holzman C, Wang J, Lucia V, Gardiner J, Breslau N. Late-preterm birth and its association with cognitive and socioemotional outcomes at 6 years of age. Pediatrics 2010; 126: 1124-1131.

78 Coffman S. Late preterm infants and risk for RSV. MCN Am J Matern Child Nurs 2009; 34: 378-384.

79 Lanari M, Silvestri M, Rossi GA. Respiratory syncytial virus risk factors in late preterm infants. J Matern Fetal Neonat Med 2009; 22(Suppl 3): 102-107.

80 Lanari M, Silvestri M, Rossi GA. Palivizumab prophylaxis in 'late preterm' newborns. J Matern Fetal Neonatal Med 2010; 23(Suppl 3): 53-55.

81 Langkamp DL, Langhough R. What do parents of preterm infants know about diphtheria, tetanus, and pertussis immunizations? Am J Perinatol 1993; 10: 187-189.

82 Pikering LKB, Lockwood CJ, Kimberlin DW, Long SS. Elk Grove Village, IL: American Academy of Pediatrics 2009.

83 National Perinatal Association. Respiratory syncytial virus prevention 2010. Neonatal Intensive Care 2010; 23: 41-4452.

84 Bull MJ, Engle WA. The Committee on Injury, Violence, and Poison Prevention and the Committee on Fetus and Newborn. Safe Transportation of Preterm and Low Birth Weight Infants at Hospital Discharge. Pediatrics 2009; 123: 1424-1429.

85 van Baar AL, Vermaa J, Knots E, de Kleine MJ, Soons P. Functioning at school age of moderately preterm children born at 32 to 36 weeks' gestational age. Pediatrics 2009; 124: 251-257.

86 Linnet KM, Wisborg K, Agerbo E, Secher NJ, Thomsen PH, Henriksen TB. Gestational age, birth weight, and the risk of hyperkinetic disorder. Arch Dis Child 2006; 91: 655-660.

87 Henderson-Smart DJ. The effect of gestational age on the incidence and duration of recurrent apnoea in newborn babies. Aust Paediatr J 1981; 17: 273-276.

88 Escobar GJ, Joffe S, Gardner MN, Armstrong MA, Folck BF, Carpenter DM. Rehospitalization in the first two weeks after discharge from the neonatal intensive care unit. Pediatrics 1999; 104: e2.

89 California Perinatal Quality Care Collaborative (CPQCC). Care and Management of the Late Preterm Infant Toolkit. CPQCC: Stanford, CA, 2007.

90 Hill PD, Aldag JC, Chatterton RT, Zinaman M. Comparison of milk output between mothers of preterm and term infants: the first 6 weeks after birth. J Hum Lact 2005; 21: 22-30.
91 Gourley GR, Kreamer B, Cohnen M, Kosorok MR. Neonatal jaundice and diet. Arch Pediatr Adolesc Med 1999; 153: 184-188.

92 Shapiro SM. Chronic bilirubin encephalopathy: diagnosis and outcome. Semin Fetal Neonatal Med 2010; 15: 157-163.

93 Purisch SE, DeFranco EA, Muglia L, Odibo AO, Stamilio DM. Preterm birth in pregnancies complicated by major congenital malformations: a populationbased study. Am J Obstet Gynecol 2008; 199(287): e1-8.

94 Leach CE, Blair PS, Fleming PJ, Smith IJ, Platt MW, Berry PJ et al. Epidemiology of SIDS and explained sudden infant deaths. Pediatrics 1999; 104: e43.

95 American Academy of Pediatrics AAP Task Force on Infant Positioning and SIDS. Positioning and SIDS. Pediatrics 1992; 89: 1120-1126.

96 American Academy of Pediatrics AAP Task Force on Infant Positioning and SIDS. Positioning and sudden infant death syndrome (SIDS): update. Pediatrics 1996; 98: $1216-1218$.

97 American Academy of Pediatrics AAP Task Force on Infant Positioning and SIDS. Does bed sharing affect the risk of SIDS? Pediatrics 1997; 100: 272.

98 American Academy of Pediatrics Task Force on Sudden Infant Death Syndrome. Technical report. SIDS and other sleep-related infant deaths: expansion of recommendations for a safe infant sleeping environment. Pediatrics 2011; 128: e1341-e1367.

99 American Academy of Pediatrics Task Force on Sudden Infant Death Syndrome. Policy statement. SIDS and other sleep-related infant deaths: expansion of recommendations for a safe infant sleeping environment. Pediatrics 2011; 128: 1030-1039.

100 Schore AN. Contributions from the decade of the brain to infant mental health: an overview. Infant Ment Health J 2001; 22: 1-698.

101 Schore AN. Effects of a secure attachment relationship on right brain development, affect regulation, and infant mental health. Infant Ment Health J 2001; 22: 7-66.

102 Schore AN. The effects of early relational trauma on right brain development, affect regulation, and infant mental health. Infant Ment Health J 2001; 22: 201-269.

103 Fonagy $\mathrm{P}$, Target $\mathrm{M}$. Bridging the transmission gap: an end to an important mystery of attachment research? Attach Hum Dev 2005; 7: 333-343.

104 Moorcroft KE, Marshall JL, McCormick FM. Association between timing of introducing solid foods and obesity in infancy and childhood: a systematic review. Matern Child Nutr 2011; 7: 3-26.

105 Gunville CF, Sontak MK, Stratton KA, Ranade DJ, Abman SH, Mourani PM. Scope and impact of early and late preterm infants admitted to the PICU with respiratory illness. J Pediatr 2010; 157(209-214): e1.

106 Moster D, Lie RT, Markestad T. Long-term medical and social consequences of preterm birth. N Engl J Med 2008; 359: 262-273.

107 Marret S, Ancel PY, Marpeau L, Marchand L, Pierrat V, Larroque B et al. Neonatal and 5-year outcomes after birth at 30-34 weeks of gestation. Obstet Gynecol 2007; 110: 72-80.

108 Chisin R, Perlman M, Sohmer H. Cochlear and brain stem responses in hearing loss following neonatal hyperbilirubinemia. Ann Otol Rhinol Laryngol 1979; 88: 352-357.

109 Adams-Chapman I. Neurodevelopmental outcome of the late preterm infant. Clin Perinatol 2006; 33: 947-964.

110 Morse SB, TY, Roth J. School-age outcomes of healthy near-term infants (34-37 weeks) versus healthy term infants (38-42 weeks). Pediatr Res 2006.

111 Lindstrom K, Winbladh B, Haglund B, Hjern A. Preterm infants as young adults: a Swedish national cohort study. Pediatrics 2007; 120: 70-77.

112 McGowan JE, Alderdice FA, Holmes VA, Johnston L. Early childhood development of late-preterm infants: a systematic review. Pediatrics 2011; 127: 1111-1124.

113 Morse SB, Zheng H, Tang Y, Roth J. Early school-age outcomes of late preterm infants. Pediatrics 2009; 123: e622-629.

114 Huddy $\mathrm{CL}$, Johnson A, Hope PL. Educational and behavioural problems in babies of 32-35 weeks gestation. Arch Dis Child Fetal Neonatal. (Ed 2001; 85: F23-28.

115 Kalia JL, Visintainer P, Brumberg HL, Pici M, Kase J. Comparison of enrollment in interventional therapies between late-preterm and very preterm infants at 12 months' corrected age. Pediatrics 2009; 123: 804-809.

116 Petrini JR, Dias T, McCormick MC, Massolo ML, Green NS, Escobar GJ. Increased risk of adverse neurological development for late preterm infants. J Pediatr 2009; 154: 169-176.

117 Takikawa, Debby, Contey, Carrie. CALMS A Guide to Soothing Your Baby, 2nd ed. Los Olivos, CA: Hana Peace Works, 2012. National Center on Shaken Baby Syndrome). www.dontshake.com).

118 Goyal NK, Fiks AG, Lorch SA. Association of late preterm birth with asthma in young children: practice-based study. Pediatrics 2011; 128(4): e1-e9.

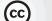

This work is licensed under a Creative Commons AttributionNonCommercial-NoDerivs 3.0 Unported License. To view a copy of this license, visit http://creativecommons.org/licenses/by-nc-nd/3.0/ 


\section{Collaborative Partners}

Thank you to the following individuals and organizations for their participation in the initial development and review of the Multidisciplinary Guidelines for the Care of Late Preterm Infants.

Academy of Neonatal Nursing

Jan Thape, MSN, RNC NIC

American Academy of Pediatrics

American College of Nurse-Midwives

Association of Women's Health, Obstetric and Neonatal Nurses

Case Management Society of America

Council of International Neonatal Nurses, Inc.

Carole Kenner, PbD, RNC, FAAN

March of Dimes

National Association of Neonatal Nurses

National Association of Neonatal Therapists

Sue Ludwig, OTR/L, NTMTC

National Association of Pediatric Nurse Practitioners

Jane K. O'Donnell RN, MS, PNP-BC

National Association of Perinatal Social Workers

Debby Segi-Kovach, LCSW

National Healthy Mothers, Healthy Babies Coalition

Judy Meehan

NPA Board Member

Diane Bolzak, MPH

NPA Board Member

Mothers \& Babies Perinatal

Network of SCNY

Sharon Chesna, MPA

NPA Board Member

Newborn Associates

Christina Glick, MD, FAAP, IBCLC

NPA Board Member

Neonatal Nurse Practitioner Program, Vanderbilt University School of Nursing

Karen D'Apolito, PhD, APRN, NNP-BC, FAAN

Nurse-Family Partnership

Oklahoma Infant Alliance

\section{Endorsing Organizations}

Thank you to the following organizations for their review and endorsement of the Multidisciplinary Guidelines for the Care of Late Preterm Infants.

Academy of Neonatal Nursing

American Academy of Pediatrics

American College of Nurse-Midwives

Association of Women's Health, Obstetric and Neonatal Nurses

Council of International Neonatal Nurses, Inc

Hand To Hold

National Association of Neonatal Nurses

National Association of Neonatal Therapists

National Association of Perinatal Social Workers

National Healthy Mothers, Healthy Babies Coalition

Nurse-Family Partnership

Oklahoma Infant Alliance

Preemie Parent Alliance

Zoe's New Beginnings 